\title{
Optimization of the conditions for rice bran phytate degradation by their own phytases
}

\author{
Abd-El Aziem Farouk ${ }^{1 *}$, N. Thoufeek Ahamed ${ }^{1}$, Anis Shobirin Meor Hussin ${ }^{2,3,4}$, Othman Al Zahrani ${ }^{5}$, Saqer Alotaibi ${ }^{1}$ \\ ${ }^{1}$ Molecular Biotechnology \& Utilization of Resources Research Group, Department of Biotechnology, Faculty of Science, Taif University, Al-Hawiya 888, \\ Kingdom of Saudi Arabia, ${ }^{2}$ Department of Food Technology, University Putra Malaysia, 43400 UPM Serdang, Selangor Darul Ehsan, Malaysia, ${ }^{3}$ Department \\ of Food Science, Faculty of Food Science and Technology, University Putra Malaysia, 43400 UPM Serdang, Selangor Darul Ehsan, Malaysia, ${ }^{4} \mathrm{Halal}$ Products \\ Research Institute, University Putra Malaysia, 43400 UPM Serdang, Selangor Darul Ehsan, Malaysia, ${ }^{5}$ Department of Biology, Faculty of Science, Taif University, \\ Al-Hawiya 888, Kingdom of Saudi Arabia
}

\begin{tabular}{l}
\hline ARTICLE INFO \\
\hline Article history: \\
Received on: October 23, 2017 \\
Accepted on: December 14, 2017 \\
Available online: April 05, 2018
\end{tabular}

Key words:

Phytate,

Phytase activity,

Rice bran,

Nutritional value

\begin{abstract}
The rice bran by-product of rice during milling process chemically contains moisture, ash, crude protein (12\%), crude fat $(15 \%)$, crude fiber $7 \%$, crude carbohydrate $(31.1 \%)$, and energy. It contains high phytate and dietary fiber contents. The cereal whole paddy after milling produces $8 \%$ of rice bran. Rice bran amino acid profile has been normally suggested to be superior to cereal grain proteins. Existing phytase within the rice bran generally improves phytate phosphorus utilizations. The present study has been conducted to find the effect of phytase activity of rice bran against five different temperatures and also the effect of phytase activity of rice bran against five different temperatures at optimum $\mathrm{pH}$ 5.5. The results showed that as the concentration of rice bran increases from 0 to $20 \%$, the phytase activity also increased. The optimum phytase activity was found at $10 \%$ concentration of rice bran at $37^{\circ} \mathrm{C}$. Moreover, an increase in phytase activity at the same concentration of rice bran was observed while adjusting the $\mathrm{pH}$ at $\mathrm{pH} 5.5$. The four concentrations of rice bran showed gradual increase in activity at $50^{\circ} \mathrm{C}$ which was directly proportional to the concentrations of rice bran and comparatively better while adjusting the $\mathrm{pH}$ at $\mathrm{pH} 5.5$. Around two-fold increase in activity was observed at room temperature and $50^{\circ} \mathrm{C}$ when the concentration of rice bran was increased from 5 to $20 \%$ with and without $\mathrm{pH} 5.5$ adjustments.
\end{abstract}

\section{INTRODUCTION}

Rice is produced around 670 MMT every year compared to 680 MMT for wheat, 440 MMT for oilseeds, and 1090 MMT for coarse grains in $28 \%$ world's landscape. 161.1 million hectares of rice-cultivated area throughout worldwide [1] and around 114 nations grow rice and more than 50 have yearly productions of 100,000 metric tons or more. There are more than 100 varieties of rice are grown in the world accounting for about $25 \%$ of the world's nourishment grain generation [2]. China, India, Indonesia, Bangladesh, Vietnam, Thailand, Myanmar, Philippines, Brazil, Japan, and the United States are the 11 countries producing $28.2 \%, 22.4 \%, 8.8 \%, 6.5 \%, 5.9 \%, 4.6 \%, 4.2 \%, 2.4 \%, 1.7 \%$, $17 \%$, and $13 \%$ of the world production of rice. The major paddy producers China and India with their pooled production account nearly half of the total world's paddy production. Milling of paddy yields $70 \%$

*Corresponding Author:

Prof. Dr. Abd-El Aziem Farouk,

Molecular Biotechnology and Utilization of Resources Research Group,

Department of Biotechnology, Faculty of Science, Taif University,

Al-Hawiya 888, Zip Code 21974, Kingdom of Saudi Arabia.

Phone: +966569999386 .

Email: Faroukgad@gmail.com of rice (endosperm) as the major product and byproducts comprising $20 \%$ rice husk, $8 \%$ rice bran, and $2 \%$ rice germ $[3,4]$. The world's $70 \%$ population has the principal food as rice and its one-tenth of the harvested rice is rice bran (approximately 60 million metric tons). In 2001, The world production of paddy in 2017 was 711.5 MMT [5]. Consistently, every year huge amounts of rice bran around 63 to 76 million tons produced in the world and over $90 \%$ rice bran are sold as animal field. Diverse food products can be formulated with 5-10\% rice bran [6-8].

The nutrient content of rice depends on assortment of rice soil and on the conditions they develop. Pre-germinated brown rice has protein $14.6 \mathrm{~g} / 100 \mathrm{~g}$ than white rice $7.3 \mathrm{~g} / 100 \mathrm{~g}$. Whereas, the fat content is higher $24.8 \mathrm{~g} / 100 \mathrm{~g}$ for pre-germinated brown rice than white rice $1.5 \mathrm{~g} / 100 \mathrm{~g}$ [9]. Commercial rice types such as brown, parboiled brown, parboiled milled, and milled rice had similar protein and crude fat contents [10]. Different rice growing conditions in various regions of the earth widely influence the type of paddy growth. The main factors such as (i) situation of the land, (ii) soil type, (iii) rice variety, (iv) climatic conditions, (v) degree of rainfall, (vi) irrigation methods and resources, and (vii) special agronomic features. 
The rice bran which is the side effect of rice during milling process chemically contains moisture, ash, crude protein, crude fat, unrefined fiber, unrefined starch, and energy. Rice bran especially composed of protein, fiber, oil, vitamins, minerals, and starch which come from endosperm in the course of polishing [11]. In Japan, rice bran is the substrate of gamma-aminobutyric acid which reduces the risk of hypertension or neural dysfunction [12]. Defatted rice bran contains various polysaccharide and dietary fiber that helps in cancer and cardiovascular diet regimen treatment $[13,14]$. The nutrients and phytochemicals in bran help the plant, and for human, the bran provides energy and some protein, antioxidants, and B vitamins [15]. Rice bran gives the majority of daily calories for many companion animals and humans [16].

The total dietary fiber content in parboiled rice and stabilized rice bran (SRB) is $27.0 \%$ and $20.9 \%$. Rice bran consists of crude protein $12 \%$, fat $15 \%$, fiber $7 \%$, and carbohydrate $31.1 \%$. It additionally contains $0.3 \mathrm{mg} / \mathrm{g} \mathrm{Ca}, 5 \mathrm{mg} / \mathrm{g} \mathrm{Mg}, 9 \mathrm{mg} / \mathrm{g}$ phytin, $43 \mu \mathrm{g} / \mathrm{g} \mathrm{Zn}, 12 \mu \mathrm{g} / \mathrm{g}$ thiamine, $1.8 \mu \mathrm{g} / \mathrm{g}$ riboflavin, and $267 \mu \mathrm{g} / \mathrm{g}$ niacin. The high phosphorous content is about $11 \mathrm{mg} / \mathrm{g}$ and silica is about $6 \mathrm{mg} / \mathrm{g}$ [17]. It incorporates varying measures of scraps of husk and impurities.

The rice bran is a pericarp or outer cuticle layer that remains underneath the hull. It gets expelled amid the processing procedure. The rice bran was scorched before a long time since considered as waste. Recent studies proved its nutritive significances. The rice bran derived from different varieties of rice contains antioxidant compounds like polyphenols, carotenoids, vitamin-E and tocotrienol which help in preventing the damage of body tissue [18]. The rice bran has 18$20 \%$ of fat, $14-15 \%$ protein, and apparent measures of minerals and vitamins. The rice bran and the bran oil have market values now.

Regular uses of rice bran are in snack foods, bakery products, dough conditioners, beverages, gluten-free foods and medical foods, isotonic drinks, iced tea drinks, enhanced juices, and mineral supplements. "Rice milk" non-dairy option to milk is produced using naturally developed rice.

Rice bran could be incorporated up to $10 \%$ without any adverse impact on laying performance, egg quality, and digestive organs [19]. Commercially by adding rice bran in the feed diets will have much profitable economic prospective.

Of $100 \mathrm{~kg}$ of paddy on milling yields, $56-58 \mathrm{~kg}$ white rice, $10-12 \mathrm{~kg}$ broken rice, $18-20 \mathrm{~kg}$ husk, and $10-12 \mathrm{~kg}$ rice bran. The lipase in rice bran rapidly degrades the oil making the bran foul and unpalatable. Stabilized (by heating $135^{\circ} \mathrm{C}$ for $3 \mathrm{~s}$ at $15 \%$ moisture and holding the extruded bran at $99^{\circ} \mathrm{C}$ for 3 min preceding cooling for deactivating the lipase) rice bran (SRB) has the stability around half year and could possibly be utilized as a food ingredient and additionally as a horse feed supplement. The wholesale price for SRB ranges from \$2.92 to $\$ 4.25 / \mathrm{kg}$, whereas rice bran and rice bran de oiled price range from $\$ 2.92$ and $4.25 / \mathrm{kg}$.

The partial replacement of maize and wheat with processed rice bran increased the body weight gain of chicks [20]. The rice bran did not modify development rate, nourish admission, or feed conversion ratio (FCR) (feed transformation proportions) of duckling at $17^{\text {th }}$ day of age. The full-fat rice bran can be used up to $45 \%$ [21] and when the rice bran level of $60 \%$ and $74.7 \%$ was used in feeds, it affected the egg production, shell thickness, and yolk color $[22,23]$. These days the rice brans are acquired by processing naturally developed excellent parboiled rice with high-protein content are generally utilized as a cattle and poultry feed. In case of chicken diets, broilers and hens ( $0-8$ weeks) up to $10 \%$; hens ( $8-20$ weeks) up to $20 \%$; and laying hens up to $30 \%$ rice bran quantity are recommended [24].

The protein $(12-16 \%)$ and fiber (10-28\%) content of rice bran vary depending on the manufacture and process. The rancidity in meat was prevented by phytic acid (PA) without risking health [25]. PA level

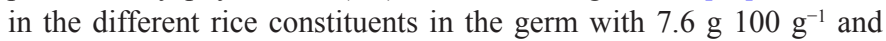

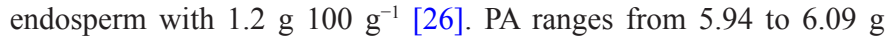
$100 \mathrm{~g}^{-1}$ [27] and responsible for antioxidant capacity and potential beneficial effects on health. Significant measure of minerals and vitamin was found in the rice bran of BRRI-28 [28]. Rice bran available as meal and pellet forms in $50 \mathrm{~kg}$ plastic bags, rice bran or cattle, fish, and animal feed cost the US \$ 500-600/Metric Ton.

Phytase can improve the nutritive value of rice bran. The growth rate increased by the addition of phytase in duck diet containing $20 \%$ rice bran $[18,20]$. Phytase hydrolyzes the phytate molecule, discharging $\mathrm{P}$ and in the meantime decreasing the concentration and in this way the counter nutritious impacts of phytate [29]. Phytase (500 unit/kg) addition to broilers diets based on corn, wheat, or barely increased apparent metabolizable energy in corn diets [30]. The FCR is generally increased (i.e. become poorer) as rice bran in that diet formula increased. The rice bran (35\%) with microbial phytase (1050 or 1400 I.U phytase/ $\mathrm{kg}$ diet) enhanced the hens day egg creation of layers $(86.7 \%$ and $88.2 \%$, individually) to be equivalent to that the production $(88.9 \%)$ of birds on the control ( $0 \%$ rice bran) diet. The eggshell thickness was found increased whereas ineffective in influencing the yolk color.

More elevated amount of rice grain decreases expensive feed price than corn or soya or corn soya-based feeds. Its few sorts of lipases drive increment in free unsaturated fats (FFA) by hydrolyzing the oil. Fast increment in the free unsaturated fat occurs up to $7-8 \%$ within $24 \mathrm{~h}$ [31]. The enzyme was dynamic up to $40^{\circ} \mathrm{C}$ and the activity declined pointedly to $65 \%$ at $60^{\circ} \mathrm{C}$ and afterward gradually decreased [32]. The hydrolytic rancidity extremely influences the nutritive value and tastefulness of rice bran [33]. Rice bran contains $15-22 \%$ oil by weight $[34,35]$. The common rice bran is a light tan, unstable meal containing a variety of particle sizes. The deleterious effects were overcome by autoclaving the bran [36].

The rice bran has no any toxicity detected toward animal and human. Furthermore, it is not harmful for the end product. Higher in fiber, bulky, and nutritional valued rice bran becomes rancid due to its high unsaturated fat content. However, still the rice bran is an ideal choice. Higher intake of rice bran as a whole grain was connected with a brought down danger of hypertension [37]. The dietary rice bran may exert valuable impacts against breast, lung, liver, and colorectal cancer [14]. Therefore, in our present study tried to use the constitutive rice bran phytases for dephosphorylation and degradation of rice bran to increase the nutritional value of rice bran to optimize by selecting optimal rice bran concentration, temperature, and $\mathrm{pH}$ for enzyme dephosphorylation.

\section{MATERIALS AND METHODS}

\subsection{Raw Material and Chemicals}

The rice bran (after milling of rough rice of Oryza sativa L. CV) was kindly given by Ministry of Primary Resources and Tourism, Brunei

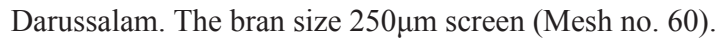

The chemicals used were $5 \mathrm{~N}$ sulfuric acid: $10 \mathrm{mM}$ ammonium molybdate, $1.0 \mathrm{M}$ citric acid, and sodium acetate buffer were purchased 
from Sigma-Aldrich Chemical Co., (St. Louis, Mo, USA). Highperformance liquid chromatography grade ethyl acetate and ethanol were purchased from BHD (Poole, UK) and were obtained from Fluka Chemical (Buchs, Switzerland). All chemicals and reagents were an analytical grade.

\subsection{Effect of Phytase Activity of Rice Bran at Various Temperatures}

The rice bran with different concentrations from 0 to $20 \%$ (w/v) in sterilized distilled water was prepared. All the mixture were stirred for $10 \mathrm{~min}$ and were incubated in the sterilized $20 \mathrm{ml}$ glass bottles at five various temperatures $\left(4^{\circ} \mathrm{C}\right.$, room temperature $\left[\mathrm{RT} 25^{\circ} \mathrm{C}\right],-18^{\circ} \mathrm{C}, 37^{\circ} \mathrm{C}$, and $50^{\circ} \mathrm{C}$ ) for $1 \mathrm{~h}$. After incubation, these slurries were centrifuged for $10 \mathrm{~min}$ at $10,000 \mathrm{rpm}$. The supernatants were decanted and measured for phytase activity in a MR96A microplate reader.

\subsection{Phytase Activity Assay}

The supernatant of rice bran was subjected to phytase measurements at $28^{\circ} \mathrm{C}$. Exactly $50 \mu \mathrm{l}$ of supernatants were used. The liberated inorganic phosphate was measured utilizing an alteration of the ammonium molybdate strategy [38]. A newly prepared solution of acetone: $5 \mathrm{~N}$ sulfuric acid: $10 \mathrm{mM}$ ammonium molybdate $(2: 1: 1 \mathrm{v} / \mathrm{v})$ and thereafter $10 \mu \mathrm{l}$ of $1.0 \mathrm{M}$ citric acid were added to $50 \mu \mathrm{l}$ of the rice bran mixture for the estimation of absorbance. The phytase activity with and without rice bran (control) was carried out. The rice bran filtrates were measured for phytase activity in microplate reader MR96A (Shenzhen Mindray BioMedical Electronics Co., Ltd.) at a primary wavelength of $405 \mathrm{~nm}$ and a secondary wavelength of $450 \mathrm{~nm}$. To quantify the phosphate released, a calibration curve was constructed within the range of 5-1200 $\mathrm{mM}$ phosphate.

The phytase activity was calculated from an average of at least three phytase assay measurements. One unit (U) of phytase activity was defined as the concentration of inorganic phosphate, in $\mu$ mol, released per min per $\mathrm{mL}$ of enzyme preparation $(\mathrm{U} / \mathrm{ml})$. The activity was calculated using the slope of the straight line resulting from the assay with the sample (absorbance/minute) and the slope of the straight line arising from the standard curve (absorbance/ $\mu \mathrm{mol}$ of $\mathrm{P}$ ).

\subsection{Effect of Phytase Activity of Rice Bran Against Five Different Temperatures at Optimum pH 5.5}

The rice bran with different concentrations of $0-20 \%(\mathrm{w} / \mathrm{v})$ and $\mathrm{pH}$ was adjusted to 5.5 using sterilized $1 \mathrm{~mm}$ sodium acetate buffer solution. The mixture was after stirring for $10 \mathrm{~min}$. They were incubated in sterilized $20 \mathrm{ml}$ glass bottles at five various temperatures $\left(4^{\circ} \mathrm{C}, \mathrm{RT}\left[25^{\circ} \mathrm{C}\right],-18^{\circ} \mathrm{C}\right.$, $37^{\circ} \mathrm{C}$, and $50^{\circ} \mathrm{C}$ ) for $1 \mathrm{~h}$. After incubation, these slurries were centrifuged for $10 \mathrm{~min}$ at $10,000 \mathrm{rpm}$ and the supernatants were decanted. The phytase activity was measured in a MR96A microplate reader as before [23].

\section{RESULTS AND DISCUSSION}

The phytase activity of rice bran without any additives tested at various temperatures of incubation showed diverse results. The increase in phytase activity in all concentrations of rice bran was observed, and the activity increased from $\mathrm{RT}$ to $50^{\circ} \mathrm{C}$ when the rice bran concentrations increased from 0 to $20 \%$. The rice bran concentration $(10 \%)$ at $37^{\circ} \mathrm{C}$ showed optimum activity. Even at $-20^{\circ} \mathrm{C}$ and $4^{\circ} \mathrm{C}$ considerable activity was noticed. The phytase activity varied regardless of temperature at fixed rice bran concentrations. Higher activity was found in $20 \%$ rice bran concentrations than 5\% [Figure 1].
The phytase activity of rice bran without any additives was tested at different incubation temperature with adjusted $\mathrm{pH} 5.5$ also showed varied results. The phytase activity was clearly noticed in all various concentrations. Increase in activity noticed when rice bran concentrations increased at all temperatures. Rice bran concentration $(10 \%)$ at $50^{\circ} \mathrm{C}$ showed optimum activity at $\mathrm{pH} 5.5$. Even at $-20^{\circ} \mathrm{C}$ and $4^{\circ} \mathrm{C}$ substantial activity was noticed. The lipase was found active up to $40^{\circ} \mathrm{C}$ and its activity declined at $60^{\circ} \mathrm{C}$ was reported earlier [32], by changing the $\mathrm{pH}$ of rice bran, the optimum phytase activity was obtained at $50^{\circ} \mathrm{C}$.

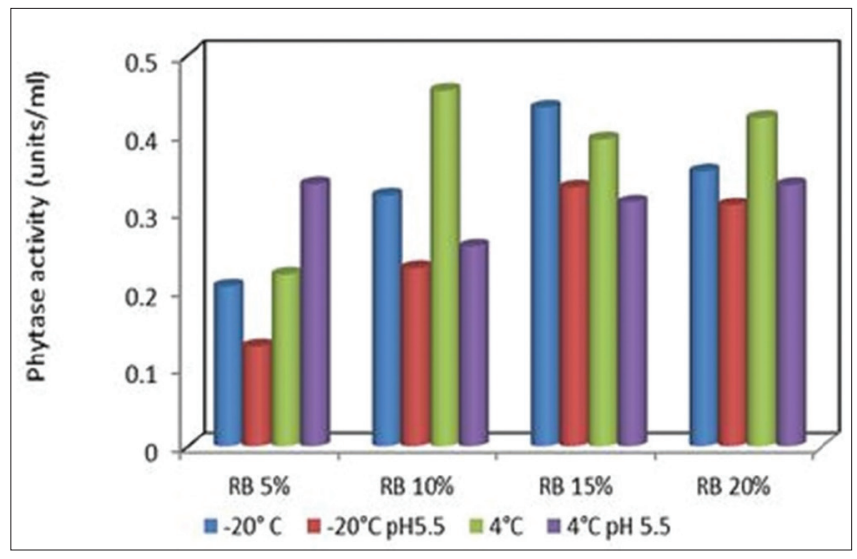

Figure 1: Phytase activity (units $/ \mathrm{ml}$ ) Vs various concentrations of rice bran with and without $\mathrm{pH} 5.5$ at $-20^{\circ} \mathrm{C}$ and $4^{\circ} \mathrm{C}$

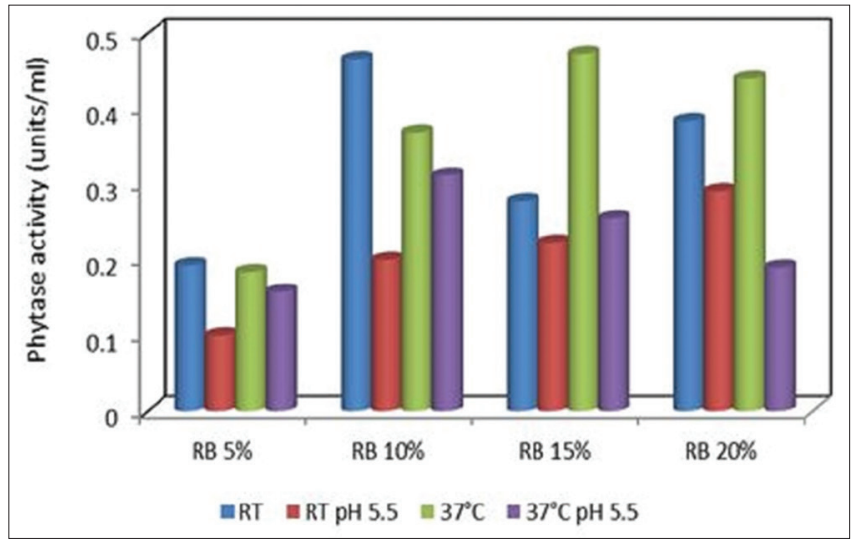

Figure 2: Phytase activity (units $/ \mathrm{ml}$ ) Vs various concentrations of rice bran with and without $\mathrm{pH} 5.5$ at $\mathrm{RT}\left(25^{\circ} \mathrm{C}\right) \& 37^{\circ}$

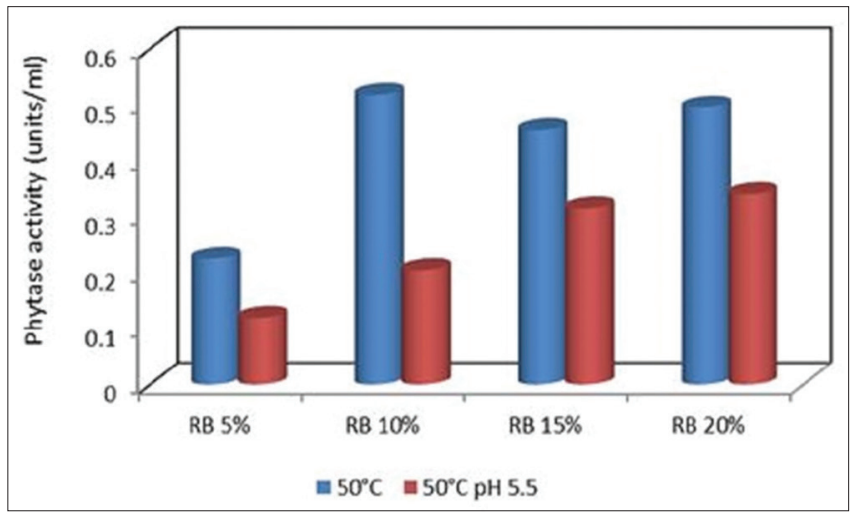

Figure 3: Phytase activity (units $/ \mathrm{ml}$ ) Vs various concentrations of rice bran with and without $\mathrm{pH} 5.5$ at $50^{\circ} \mathrm{C}$ 


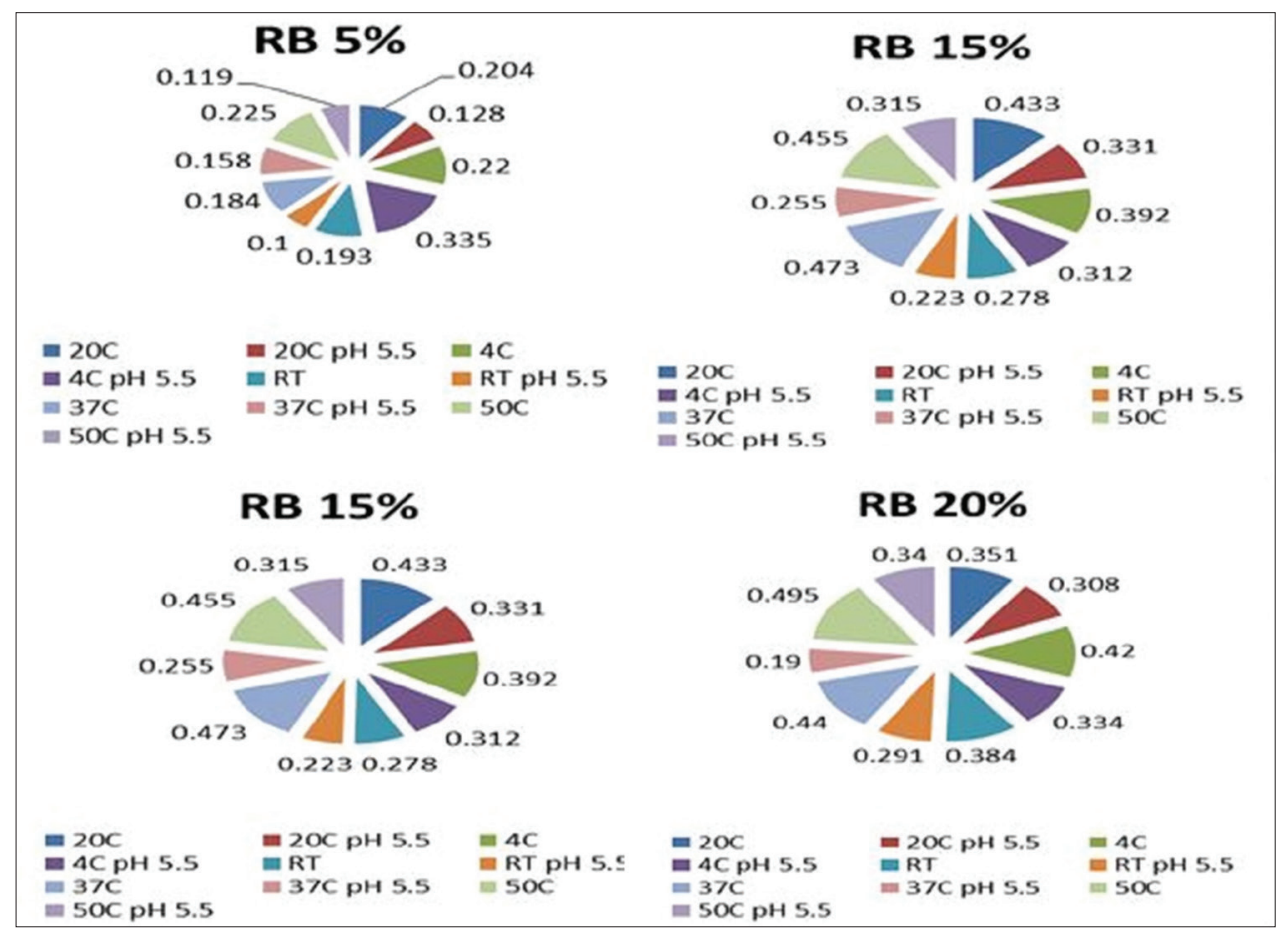

Figure 4: Comparative study of Phytase activity of different concentrations of rice bran without additives at various temperatures

In general, the $\mathrm{pH}$ of commercial rice bran varies from 6.0 to 6.9 . The enzyme presents in rice bran is temperature and $\mathrm{pH}$ sensitive. The rice bran lipase is known to have a $\mathrm{pH}$ optimum of $7.5-8.0$ at $37^{\circ} \mathrm{C}$. Furthermore, activity reduced depends on the increase or decrease in $\mathrm{pH}$ levels. The enzyme was inactivated by incubation for $15 \mathrm{~min}$ at $60^{\circ} \mathrm{C}$ was reported earlier [39]. Approximately $90 \%$ of rice bran phosphorous is a product of phytate degradation. In the $\mathrm{pH}$ range 4.15.2 (acidic), the solubility of total phosphorous is maximum of $80 \%$ and increased at 5 to $\mathrm{pH}$ 6.2. At $\mathrm{pH} 2$ (highly acidic), the total phosphorous solubility was very low was also reported [40]. The rice bran enzyme glutamate decarboxylase was active at $\mathrm{pH} 5.5$ and $40^{\circ} \mathrm{C}$ and retained $80 \%$ of its original activity in the $\mathrm{pH}$ range 5-9 and the temperature range $30-50^{\circ} \mathrm{C}$ was also reported [41]. The enzyme activity for phytase degrading enzymes from rice bran has $\mathrm{pH} 5.5$ as optimal for plant enzymes. The cereal phytases have optimal $\mathrm{pH}$ of 5.0-6.0. The phytase from rye with optimal activity for dephosphorylation at $\mathrm{pH} 6$ was also reported $[42,43]$. At same concentration of rice bran at constant optimum $\mathrm{pH}$, varied phytase activities irrespective of temperature was also observed. Higher activity was found in $20 \%$ concentrations than $5 \%$ at all different temperatures [Figure 2].

The existing phytase within the rice bran improves phytate phosphorus utilization [29] can be a reason for general phytase activity increase with the increase in rice bran concentrations. Addition of phytase to diets containing rice bran definitely improved further [30]. Furthermore, by autoclaving the rice bran, deleterious effects can be overcome may need further study. In case of chicken diets, broilers and hens ( $0-8$ weeks) up to $10 \%$; hens ( $8-20$ weeks) up to $20 \%$ rice bran, and in duck diet containing $20 \%$ rice bran were reported [44]. When comparing the rice bran at $\mathrm{pH} 5.5$, the results showed that the phytase activity increased than the rice bran without $\mathrm{pH}$ adjustment. The phytase activity corresponding to the gradual increase in rice bran concentrations is shown in Figures 1-3. A comparative study of phytase activity of various concentrations of rice bran without additives at various temperatures is individually shown in the pie charts in Figure 4.

\section{CONCLUSION}

The data presented showed optimal activity of phytase was found at the concentration of rice bran $10 \%$, at $37^{\circ} \mathrm{C}$, and $\mathrm{pH}$ of 5.5. The time of incubation, temperature optima, and rice bran concentrations were also important for efficient dephosphorylation processes. The study concludes rice bran phytase was still active after milling and polishing processes of rice.

\section{ACKNOWLEDGMENT}

The authors express their gratitude to Taif University, Al-Hawiya 888, Kingdom of Saudi Arabia, especially the support of Research Centre at Taif University, Saudi Arabia, for its support for our research group and efforts.

\section{REFERENCES}

1. World Rice Acreage from 2008/2009 to 2015/2016 (In Million Hectares): Statista; 2017. Available from: https://www.statista.com/ statistics/271969/world-rice-acreage-since-2008/.

2. Hernandez N, Rodriguez ME, Gonzalez F, Lopez-Munguia A. Enzymatic treatment of rice bran to improve processing. JAOCS 2000;77:177-80.

3. Van Hoed V, Depaemelaere G, Villa AJ, Santiwattana P, Verh AR, De Greytb W. Influence of chemical refining on the major and minor components of rice bran oil. JAOCS 2006;83:315-21.

4. de Deckere EA, Korver O. Minor constituents of rice bran oil as functional foods. Nutr Rev 1996;54:S120-6.

5. FAO. Nutritional Contribution of Rice and Impact of Biotechnology and Biodiversity in Rice-consuming Countries; 2001. Available from: https://www.statista.com/statistics/255937/leading-rice-producersworldwide/. 
6. Available from: https://www.statista.com/statistics/255937/leadingrice-producers-worldwide/.

7. Faccin GL, Vieira LN, Miotto LA, Barreto PLM, Amante ER, Chemical, sensorial and rheological properties of a new organic rice bran beverage. Rice Sci 2009;16:226-34.

8. Hallen E, Ibanoglu S, Ainsworth P. Effect of fermented/germinated cowpea flour addition on the rheological and baking properties of wheat flour. J Food Eng 2004;63:177-84.

9. Seki T, Nagase R, Torimitsu M, Yanagi M, Ito Y, Kise M, et al. Insoluble fiber is a major constituent responsible for lowering the post-prandial blood, glucose concentration in the pre-germinated brown rice. Biol Pharm Bull 2005;28:1539-41.

10. Heinemann RJ, Fagundes PL, Penteado PE, Lanfer-Marquez UM. Comparative study of nutrient composition of commercial brown, parboiled and milled rice from Brazil. J Food Composit Anal 2005; 18:287-96.

11. Al-Okbi SY, Hussein AM, Hamed IM, Mohamed DA, Helal AM. Chemical, rheological, sensorial and functional properties of gelatinized corn-rice bran flour composite corn flakes and tortilla chips. J Food Process Preserv 2014;38:83-9.

12. Arai S. Global view on functional foods: Asian perspectives. Br J Nutr 2002;88 Suppl 2:S139-43.

13. Rohman A, Helmiyati S, Hapsari M, Setyaningrum DL. Rice in health and nutrition. Int Food Res J 2014;21:13-24.

14. Henderson AJ, Ollila CA, Kumar A, Borresen EC, Raina K, Agarwal $\mathrm{R}$, et al. Chemopreventive properties of dietary rice bran: Current status and future prospects. Adv Nutr 2012;3:643-53.

15. Orthoefer FT. Rice brain oil. In: Bailey's Industrial Oil and Fat Products. $6^{\text {th }}$ edition. New York: John Wiley \& Sons, Inc.; 2005.

16. Ryan EP. Bioactive food components and health properties of rice bran. J Am Vet Med Assoc 2011;238:593-600.

17. Luh BS, Barber S, de Barger CB. In: Luh BS, editor. Rice Utilization. Vol. II. New York: Van Nostrand Rein Hold; 1991.

18. Radim A. Effects of Rice Bran and Phytase Supplementation on Egg Laying Performance and Egg Quality of Laying Hens. MD. Thesis; 2006.

19. Samli HE, Nizamettin S, Hasan A, Aylin A. Using rice bran in laying hen diets. J Central Eur Agric 2006;7:1.

20. Shaheen M, Ahmad I, Anjum FM, Syed QA, Saeed MK. Effect of processed rice bran on growth performance of broiler chicks from Pakistan. Bulg J Agric Sci 2015;21:440-5.

21. Balnave D. Egg weight and production responses of laying hens fed rice Pollard. J Sci Food Agric 1982;33:231-6.

22. Majun GK, Payne CG. Autoclaved rice bran in layers' diets. Br Poult Sci 1977;18:201-3.

23. Din MG, Sunde ML, Bird HR. Effect of feeding plant byproducts diets on growth and egg production. Poult Sci 1979;58:1274-83.

24. Samli HE, Senkoylu N, Akyurek H, Agma AA. Using rice bran in laying hen diets. J Central Eur Agric 2006;7:135-9.

25. Harbach AP, Costa MC, Soares AL, Bridi AM, Shimokomaki M, Silva CA, et al. Dietary corn germ containing phytic acid prevents pork meat lipid oxidation while maintaining normal animal growth performance. Food Chem 2007;100:1630-3.

26. Dell LO, De Boland A, Koirtyohann SR. Distribution of phytate and nutritionally important elements among the morphological components of cereal grains. J Agric Food Chem 1972;20:718-21.

27. Kasim AB. Edwards H Jr. The analysis for inositol phosphate forms in feed ingredients. J Food Sci Agric 1998;76:1-9.

28. Satter MA, Ara H, Jabin SA, Abedin N, Azad AK, Hossain A, et al.
Nutritional composition and stabilization of local variety rice bran BRRI-28. Int J Sci Technol 2014;3:306-13.

29. Dos Santos TT, Srinongkote S, Bedford MR, Walk CL. Effect of high phytase inclusion rates on performance of broilers fed diets not severely limited in available phosphorus. Asian Australas J Anim Sci 2013;26:227-32.

30. Juanpere J, Pérez-Vendrell AM, Angulo E, Brufau J. Assessment of potential interaction between phytase and glycosidase enzyme supplementation on nutrient digestibility in broilers. Poult Sci 2005;84:571-80.

31. Ramezanzadeh FM, Rao RM, Windhauser M, Prinyawiwatkul RT, Marshall WE. Prevention of hydrolytic rancidity in bran during storage. J Agric Food Chem 1999;47:3050-2.

32. Bhardwaj K, Raju A, Rajasekharan R. Identifi cation, purification, and characterization of a thermally stable lipase from rice bran. A new member of the (phospho) lipase family. Plant Physiol 2001;127:1728-38.

33. Rajeshwara AN, Prakash V. Purification and characterization of lipase from rice (Oryza sativa L.) bran. Nahrung 1995;39:406-18.

34. Orthpoefer FT. Rice bran oil. Healthy lipid source. Food Technol 1996;50:62-4.

35. Patel P, Walker TH. Supercritical Fluid Extraction of Rice Bran Oil as Affected by Extraction Time and Other Extraction Conditions. IBE National Meeting, University of Arkansas; 2004.

36. De Dios CV, Natividad DG, Tampoc EA, Javier L. Storage Behavior of Rice and Rice Bran Under Hermetic Storage. In: Proc. Int. Conf. Controlled Atmosphere and Fumigation in Stored Products, GoldCoast Australia 8-13 ${ }^{\text {th }}$ August 2004. Israel: FTIC Ltd.; 2004. p. 405-25.

37. Wang L, Gaziano JM, Liu S, Manson JE, Buring JE, Sesso HD, et al. Whole- and refined-grain intakes and the risk of hypertension in women. Am J Clin Nutr 2007;86:472-9.

38. Heinonen JK, Lahti RJ. A new and convenient colorimetric determination of inorganic ortho-phosphate and its application to the assay of inorganic pyrophosphatase. Anal Biochem 1981;113:313-7.

39. Prabhakar JV, Venkatesh KV. A simple chemical method for stabilization of rice bran. J Am Oil Chem Soc 1986;63:644-6.

40. Champagne ET, Rao RM, Liuzzio JA, Robinson JW, Gale RJ, Miller $\mathrm{F}$. The interactions of minerals, proteins, and phytic acid in rice bran. J Food Compos Anal 1986;62:231-8.

41. Wang L, Xu DX, Lv YG, Zhang H. Purification and biochemical characterisation of a novel glutamate decarboxylase from rice bran. J Food Compos Anal 1986;90:1027-33.

42. Greiner R, Alminger-Larsson M. Stereospecificity of myo-inositol hexakisphosphate dephosphorylation by phytate-degrading enzymes of cereals. J. Food Biochem 2001;25:229-48.

43. Ralf G. Activity of Escherichia coli, Aspergillus niger, and rye phytase toward partially phosphorylated myo-inositol phosphates. J Agric Food Chem 2017;65:9603-7.

44. Farrell DJ, Martin EA. Strategeis to improve the nutritive value of rice bran in poultry diets. III. The addition of inorganic phosphorus and phytase to duck diets. Brit Poult Sci 1998;39:601-11.

How to cite this article:

Farouk AE, Ahamed NT, Hussin AS, Al Zahrani O, Alotaibi S. Optimization of the conditions for rice bran phytate degradation by their own phytases. J App Biol Biotech. 2018;6(3):42-46. DOI: 10.7324/JABB.2018.60307 